\title{
LAZER E SOCIABILIDADE EM NOVO HAMBURGO: NO ESCURINHO DO CINEMA
}

\author{
Prof ${ }^{a}$. Dra. Cristina Ennes da Silva \\ Profa. Dra . Paula Regina Puhl \\ Carlos Eduardo Ströher'
}

\begin{abstract}
Resumo: O presente estudo analisa os aspectos relacionados às salas de cinema de Novo Hamburgo, no período de 1960 até 2000. Interessa-nos compreender de que forma se processaram as transformações nesses espaços, desde quando os cinemas se localizavam nas "calçadas", em chamados cine-theatros, até sua migração para o shopping center da cidade, na década de 1990. Buscamos compreender a problemática proposta através da pesquisa de informações relacionadas ao cinema na mídia impressa, representada pelo jornal $\mathrm{NH}$, de acordo com a metodologia da análise de conteúdo; bem como por meio de entrevistas de história oral com sujeitos que viveram o referido período histórico, a fim de percebermos de que forma estes acompanharam as modificações tecnológicas e como estas influenciaram seu comportamento em relação ao ato de "ir ao cinema”.
\end{abstract}

Palavras-chave: Cinema; Lazer; Sociabilidade; Memória; História Oral

\begin{abstract}
This study analyzes the aspects related to the movie theatres in Novo Hamburgo, Brazil, from 1960 to 2000. We are interested in understanding how did the transformations in these spaces took place, from the time when the movie theatres were located near the sidewalks of busy streets, in the so-called cinetheatros, up to their migration to the city's shopping mall in the 1990's. We aim to understand such proposed investigation through the research of film-related information in print media, in the NH newspaper, according to the content analysis methodology; as well as through oral history interviews with subjects that witnessed and experienced that historical period, so that we can notice how did the subjects follow the technological change and how did these changes did influence their behavior in relation to the social act of "going to the movies".
\end{abstract}

Key-words: Cinema; Leisure; Sociability; Memory; Oral History

' Centro Universitário FEEVALE. E-mail para contato: carloseduardo@feevale.br. 
Esse trabalho analisa o cinema como uma atividade de lazer e um espaço de sociabilidade na cidade de Novo Hamburgo. Interessa-nos compreender a trajetória das transformações relacionadas ao cinema, enfocando, a partir da década de 1960, os cinemas "de calçada" denominados de cine-theatros, até a sua migração para o interior do shopping center local, na década de 1990.

O estudo é parte integrante de um projeto mais amplo, intitulado "'O doce nada fazer': um estudo sobre lazer e identidade(s) em Novo Hamburgo”, vinculado ao grupo de pesquisa em Cultura e Memória da Comunidade, do Centro Universitário Feevale. ${ }^{2}$

Para a realização dessa investigação, utilizamos, num primeiro momento, a análise de conteúdo das matérias e reportagens sobre cinema publicadas no jornal local, e, posteriormente, entrevistas de história oral com sujeitos que viveram no referido período histórico, através das quais buscamos (re)construir a memória da comunidade no que se refere ao lazer e à sociabilidade ligados ao cinema.

Nossa opção pela análise de fontes impressas, mais especificamente pelo Jornal $\mathrm{NH}$, mostrou-se significativa na medida em que ele foi, e ainda é, o veículo de comunicação impresso de maior circulação da cidade de Novo Hamburgo e da região do Vale do Rio dos Sinos. O Grupo Editorial Sinos, do qual o jornal faz parte, foi fundado em dezembro de 1957 pela família Gusmão, membros proeminentes da sociedade local. ${ }^{3}$

Como metodologia de trabalho e tendo em vista a vasta quantidade de edições do periódico, o levantamento dos dados empíricos obedeceu a preceitos de seleção amostral de forma que na década de sessenta foram analisados os anos de 1960, 1961, 1963, 1964, 1967 e 1969, a fim de obtermos uma visão mais abrangente sobre o tratamento dado à temática neste período. A partir daí, decidiu-se pela alternância de anos, analisando as edições de 3 em 3 anos. Nos primeiros anos, a análise concentrou-se em todas as edições do periódico, que tinha circulação semanal. A partir do final da década de 1960, o número de edições semanais aumentou - refletindo o crescimento do jornal e da própria cidade de Novo Hamburgo -, chegando, em 1978, as 5 edições semanais (de segunda a sexta). Tendo em vista a ampliação de edições, optamos, a partir de então, por manter uma média de duas edições semanais pesquisadas, buscando contemplar os diferentes dias em proporções iguais. Na década de oitenta, o jornal passou a ter edições aos sábados e domingos, e a análise conservou a delimitação anterior, apenas incluindo estes dias na alternância. Com exceção dos primeiros anos, quando o número de edições anuais chegava a cerca de 50, a partir de 1969, o número de jornais anuais pesquisados estabilizou-se em torno de 100 edições, até o ano 2000, totalizando 1582 edições analisadas. 
As características das fontes selecionadas como material empírico para essa investigação levou-nos a optar pela metodologia da análise de conteúdo, possibilitando a análise de dados quantitativos e qualitativos acerca da temática. Bardin (1977) afirma que tal método é, na verdade, um "conjunto de técnicas de análise das comunicações", ${ }^{4}$ corresponde aos objetivos de "ultrapassagem da incerteza" e "enriquecimento da leitura”, traduzidos por "desejo de rigor e necessidade de descobrir, de adivinhar, de ir além das aparências". ${ }^{5}$

Seguindo a metodologia da análise de conteúdo, construímos categorias para melhor sistematizar os dados pesquisados, entendendo, assim como Bardin (1977), que a categorização tem como primeiro objetivo fornecer, por condensação, uma representação simplificada dos dados brutos. A análise categorial

[...] pretende tomar em consideração a totalidade de um 'texto', passando pelo crivo da classificação e do recenseamento, segundo a frequiência de presença (ou de ausência) de itens de sentido. [...] É o método das categorias, espécie de gavetas ou rubricas significativas que permitem a classificação dos elementos de significação constitutivas, da mensagem. [...] Tudo depende, no momento da escolha dos critérios de classificação, daquilo que se procura ou que se espera encontrar. ${ }^{6}$

Essa categorização levou em conta as informações vinculadas à temática central - lazer -, buscando subdividi-las conforme as peculiaridades dos dados presentes nos periódicos. Dessa forma, criamos macrocategorias conforme o tipo de atividade de lazer praticado: físico, manual, intelectual, artístico, turístico, religioso, social, ou outros. A temática cinema foi inserida como uma das subcategorias das atividades artísticas. Assim, das 1582 edições analisadas, foram encontrados 2399 eventos relacionados ao cinema conforme expresso no gráfico 1:

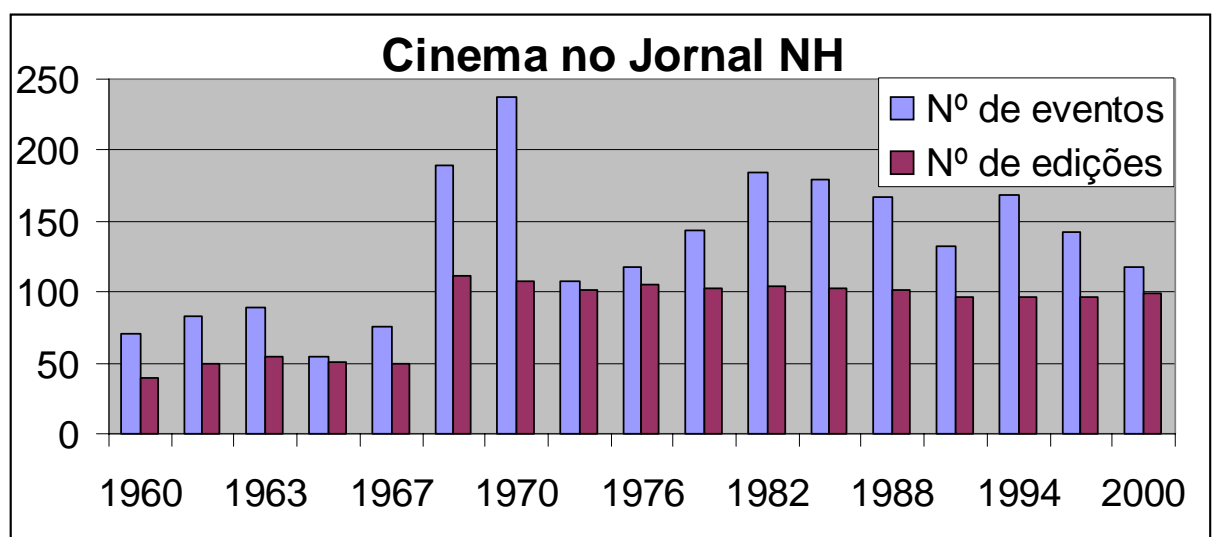

Gráfico 1: Relação entre o número de edições e de eventos relacionados ao cinema. 
Para além do levantamento de dados da mídia impressa, estabelecemos como metodologia de trabalho as entrevistas de história oral. Dessa forma, de acordo com Alberti (2005), entendemos que, como método de pesquisa, a história oral se justifica no contexto de uma investigação científica previamente definida. Para a autora, a história oral

[...] consiste na realização de entrevistas gravadas com indivíduos que participaram de, ou testemunharam, acontecimentos e conjunturas do passado e do presente. Tais entrevistas são produzidas no contexto de projetos de pesquisa, que determinam quantas e quais pessoas entrevistar, o que e como perguntar, bem como que destino será dado ao material produzido. ${ }^{7}$

Através da história oral, a percepção do passado vai sempre se modificando, uma vez que as lembranças dos depoentes fornecem perspectivas de novas interpretações. Mas, como alerta Alberti (2005), a entrevista oral não pode ser vista como a revelação do real, pois, da mesma forma que os outros tipos de fontes históricas, necessita de análise e interpretação.

\begin{abstract}
A História Oral é hoje um caminho interessante para se conhecer e registrar múltiplas possibilidades que se manifestam e dão sentido a formas de vida e escolhas de diferentes grupos sociais, em todas as camadas da sociedade. Neste sentido, ela está afinada com as novas tendências de pesquisa nas ciências humanas, que reconhecem as múltiplas influências a que estão submetidos os diferentes grupos no mundo globalizado. ${ }^{8}$
\end{abstract}

Dessa forma, as entrevistas foram realizadas após ampla investigação nas fontes impressas, tendo em vista a preparação de roteiros de entrevista - formulados com perguntas amplas, para que os entrevistados se expressassem livremente acerca das questões propostas, - perfil de número estipulado de depoentes e o tipo de entrevista a ser realizado - no caso, optamos por entrevistas temáticas. Paulatinamente os cuidados metodológicos com as fontes empíricas, buscamos compreender as categorias de análise que compõe a temática estudada, ou seja, o lazer e a sociabilidade, bem como a memória, que é evocada a partir da metodologia da história oral, pois segundo destaca Alberti (2005), o trabalho com a história oral pode mostrar o quanto a constituição da memória é objeto de constante negociação. ${ }^{9}$

\title{
A “SÉTIMA ARTE” EM NOVO HAMBURGO
}

O final do século XIX pode ser indicado como marco inicial da história do cinema no Brasil, mais especificamente, o ano de 1898, dois anos após a projeção na França feita pelos irmãos Lumière. As primeiras exibições no país aconteceram na 
Rua do Ouvidor, no Rio de Janeiro, Gomes (1996), ${ }^{10}$ indica Afonso Segreto como responsável pelo episódio, sendo que este teria feito algumas imagens da Baía de Guanabara com a câmera de filmar, comprada em suas viagens para Paris. ${ }^{11}$

As mais antigas referências sobre cinema em Novo Hamburgo reportamse ao ano de 1913, quando Adão Adolfo Schmitt alugou o salão de sua casa no bairro Hamburgo Velho para a projeção de filmes. Anos depois, Sara Lanzer, proprietária de uma casa de comércio e freqüentadora assídua do cinema, como capital obtido por um prêmio de loteria, mandou construir uma sala de projeções. Essa sala recebeu o nome de Cinema Central e funcionava na Avenida Maurício Cardoso. Na década de 40, o Cinema Central foi comprado por Lothário Blankenheim e recebeu o nome de Cine Aída.

No centro da cidade, na década de 1930, o Cinema Guarani foi construído na Avenida Pedro Adams Filho - uma das principais vias da cidade -, pela empresa Jaeger \& Venturini Ltda. Na década de 1950, a mesma empresa construiu no calçadão da General Neto o Cine Lumière e, nos anos 1960, na Pedro Adams Filho, o Cine Avenida. Nesse período também já havia o Cine Theatro Carlos Gomes, na Rua Lima e Silva, que era propriedade da família Blankenheim. ${ }^{12}$

Os Blankenheim tiveram grande destaque na trajetória histórica dos cinemas de Novo Hamburgo. Felipe fora um dos sócios fundadores do Cine Guarani, e, ao construir o Carlos Gomes, passou a administração para seu filho Lothário que era violinista e ao lado da esposa pianista, tocava antes e durante as sessões de cinema, no período em que este ainda era mudo. Posteriormente, seu filho Bodo prosseguiu administrando o cinema, que no início dos anos 1960 teve seu nome alterado para Saionara. ${ }^{13}$

Nesse período, a cidade de Novo Hamburgo, cenário da nossa pesquisa que teve a sua origem relacionada à imigração alemã no século XIX, a partir de um projeto do governo imperial brasileiro de ocupar a região meridional do país contava com uma população estimada em 70 mil habitantes e vivenciava um período de grande progresso industrial e crescimento urbano. ${ }^{14}$ Toda essa pujança econômica se manifestava, conforme observamos nas matérias do Jornal NH, também nas atividades de lazer, expressas, na maioria das vezes, através de clubes, sociedades e associações que organizavam bailes, reuniões dançantes, jantares, quermesses, concursos de beleza, competições esportivas, apresentações artísticas, etc. Além disso, os quatro cinemas locais também eram muito prestigiados pela população.

O último representante da família Blankenheim que esteve à frente do cinema nos anos 1990 foi José Carlos que, por sua ligação familiar com o "negócio de cinema”, interpreta que desde seus primórdios de existência na cidade o cinema era, efetivamente, um acontecimento de grande relevância na sociedade local: 
Imagina... há 100, 80 anos atrás, alguém trazer um cinema pra Novo Hamburgo! Tinha meia dúzia de casas, então era algo fora do comum pra época. Pegava, usava uma roupa e ia para o cinema. [...] Porque aquilo era um evento social. Tinha gente que se conhecia no cinema, namoravam no cinema, se um cara morava num bairro, o outro no outro eles se encontravam no cinema. Existia a praça da cidade e o cinema. A única coisa cultural que tinha era o cinema. Casualmente no Saionara tudo desembocava ali. Peças de teatro, espetáculos musicais e o cinema. O cinema sempre foi uma coisa muito forte..$^{15}$

Nesse excerto do depoimento podemos observar que o hábito de freqüentar o cinema extrapolava as questões exclusivas de lazer que Dumazedier ${ }^{16}(1979)$ caracteriza como as ocupações que o indivíduo se entrega de livre vontade para fins de repouso, diversão, recreação ou entretenimento - após livrar-se de suas obrigações profissionais, familiares, sócio-espirituais e sócio-políticas. Dessa forma, a freqüência ao cinema pode ser percebida, igualmente, ligada à sociabilidade, na medida em que essa se constitui uma espécie de acontecimento da "vida pública". Forma típica da sociedade burguesa, que os estudos de Pellissier (1996) apontam como sendo o "conjunto das formas concretas, das modalidades, das estruturas e dos processos de comunicação e de socialização dos indivíduos numa dada sociedade." ${ }^{17}$

Quando o depoente aponta "A única coisa cultural que tinha era o cinema”, a interpretação de sociabilidade de $\operatorname{Simmel}^{18}$ (2006) - ou seja, a "forma lúdica de sociação", que visa muito mais o prazer do contato, da interação, do que a resolução de problemas materiais da vida - sobressai-se, e cria-se aquilo que o autor apresentou como um mundo de artificial igualdade, pois, "Se a sociação é, sobretudo interação, então o caso mais puro de sociação é aquele que ocorre entre iguais, [...] modificam seu significado interno e externo para se tornarem socialmente iguais." ${ }^{19}$ Neste sentido, o cinema encarnava o espaço preferencial de sociabilidade, pois, de acordo com o depoente: "Tinha gente que se conhecia no cinema, namoravam no cinema. Se um cara morava num bairro e o outro no outro, eles se encontravam no cinema."

Num outro sentido, as lembranças do depoente remetem-nos as concepções de memória de Halbwachs, quando este indica que a memória individual existe sempre a partir de uma memória coletiva, uma vez que todas as lembranças são constituídas no interior de um grupo, pois, se entende que,

Para que a nossa memória se aproveite da memória dos outros, não basta que estes nos apresentem seus testemunhos: também é preciso que ela não tenha deixado de concordar com as memórias deles e que existam muitos pontos de contato 
entre uma e outras para que a lembrança que nos fazem recordar venha a ser reconstruída numa base comum. [...] É preciso que esta reconstrução funcione a partir de dados ou de noções comuns que estejam em nosso espírito e também no dos outros, porque elas estão sempre passando destes para aquele e vice-versa, o que será possível somente se tiverem feito parte e continuarem fazendo parte de uma mesma sociedade, de um mesmo grupo. ${ }^{20}$

Halbwachs (2006), influenciado pela sociologia durkheiminiana, enfatiza a importância do grupo social no processo de reconstituição das lembranças, visto que, a partir das vivências de determinado grupo ou das informações dadas por um de seus integrantes, as memórias individuais podem ser reconstruídas ou simuladas, passando a ser internalizadas pelo indivíduo. "Essas lembranças existem para ‘todo o mundo' nesta medida e é porque podemos nos apoiar na memória dos outros que somos capazes de recordá-las a qualquer momento e quando o desejamos." ${ }^{21}$ Desta maneira o estudo do cinema, enquanto espaço de sociabilidade e lazer, apresenta as condições necessárias que possibilitam a (re)construção da memória coletiva do grupo.

Conforme Selbach ${ }^{22}$ (1999), o cinema era um divertimento que agradava aos operários das indústrias locais, um lazer que estava ao alcance deles:

Na Cidade Industrial, os trabalhadores acorriam em massa às salas de projeção, 'para assistirem à vingança que o intérprete executa em nome delas, na medida em que o ator não somente afirma diante do aparelho sua humanidade (ou o que aparece como tal aos olhos dos espectadores), como coloca esse aparelho a serviço do seu próprio triunfo'.[sic $]^{23}$

Essa questão remete-nos aos estudos de Dumazedier (1979), na medida em que estabelece algumas propriedades das atividades que podem ser consideradas como relacionadas ao lazer: caráter liberatório, uma vez que pressupõe uma liberação de certas obrigações; caráter desinteressado, pois, a priori, não está submetida a nenhum fim lucrativo, utilitário ou ideológico; caráter hedonístico, na medida em que busca um estado de satisfação; e um caráter pessoal, pois corresponde a necessidades individuais. Mesmo assim, o lazer, embora busque a satisfação de vontades pessoais, está vinculado ao trabalho, pois o tempo livre do indivíduo depende do tempo liberado do seu trabalho, quando se permite a manifestação das atividades de lazer. Dessa forma, para o autor, "o lazer não é a ociosidade, não suprime o trabalho; o pressupõe.”24

Porém, freqüentava-se o cinema por divertimento, mas também como parte de um programa de gala, pois estes ambientes eram considerados sofisticados no período. A inauguração do Cine Lumière, em 1953, foi um acontecimento des- 
sa amplitude, em virtude da grandiosidade da sala de espetáculos - cerca de 1800 lugares, sendo o maior cinema do interior do Estado. Verena rememora o episódio:

Um dia, meu pai, que trabalhava no jornal O 5 de Abril, disse: Ah, vamos ter mais um cinema!' "Cine Lumière!” 'O que que é isso?'. Todo mundo dizia Lumiere, mas meu pai dizia que esse nome veio dos irmãos Lumière, que foram os que descobriram o cinema, e que criaram tudo isso aí. Mas o povo assim custou até que assimilou. Então, já por causa desse nome estrangeiro, as pessoas achavam que o Cine Lumière era uma coisa muito chique que não dava pro povo ir. Então as pessoas iam mais, normalmente, no Carlos Gomes. E o Lumière era uma coisa muito fantástica, porque ele já tinha aquela construção [...] super moderna. A pessoa podia ficar na extremidade, na porta da entrada, e já enxergava muito bem. Então isso foi uma coisa muito boa. Também era palco de teatro, onde o grupo da dona Olga, em que eu toquei muitas e muitas vezes. Nós tocamos cítara no palco do Lumière. Ele tinha uma acústica melhor, porque era mais moderno, era maior também..$^{25}$

O depoimento apresenta a expectativa surgida a partir da perspectiva de existência de um novo cinema e a representação acerca da grandiosidade e modernidade do local, contudo, o destaque refere-se à relação estabelecida com o espaço, ou seja, com as possibilidades que ele oferecia.

Os eventos, ocorridos nos quatro cine-teatros existentes na cidade, freqüentemente geravam grandes filas e despertavam o interesse de diferentes atores sociais, servindo de espaço de convivência para as mais diversas manifestações culturais, pois, além das sessões cinematográficas, serviam de espaço para a apresentação de peças teatrais, festivais de música, shows de orquestras, corais, etc. No entanto, podemos observar no depoimento anterior que esses espaços também apresentavam uma forma de segregação social, apesar de poderem ser freqüentados por pessoas de todas as camadas sociais, a fala da depoente ao indicar que o povo não podia ir ao cinema - expressa a exclusão.

Em outro depoimento aflorou, pontualmente, a questão relacionada às diferenças econômicas como fator de segregação nos espaços das salas de cinema. Em sua entrevista, Hedviges relembra a questão com um certo constrangimento,

[...] a classe alta sentava quase sempre em cima, porque tinha o andar de cima, as cadeiras, e tinha a parte de baixo. [...] No cinema Carlos Gomes e no Cine Aída de Hamburgo Velho, iam pessoas de uma classe... ahm, eu não vou dizer baixa, uma classe um pouquinho inferior a quem ia ao Lumière, em Novo Hamburgo. E o Lumière era o mais novo, maior e mais caro, 
também cobrava um pouco mais que os outros cinemas. Tinha mais conforto porque as poltronas eram melhores, o espaço era maior, tudo isso. ${ }^{26}$

Para o entrevistado Paulo, era comum as pessoas da área mais popular da cidade sentirem-se intimidadas ao freqüentarem um espaço suntuoso, como o cinema Lumière:

[...] eles já entram quando já está apagada a luz, não entram no início. Mas eles têm interesse em ver o filme, se sentem um pouco deslocados, mas dão jeito de sentar, ou eles ficam nos primeiros bancos atrás, ou se está escuro eles entram sempre na frente, isso acontecia. Tinha os moreninhos ali da Oswaldo Cruz... ${ }^{27}$

Observa-se aqui a questão étnica associada à econômica, quando o depoente destaca a tentativa de indivíduos dos grupos de menor potencial econômico inserirem-se no espaço do cinema desapercebidamente e finaliza a fala se referindo aos "moreninhos ali da Oswaldo Cruz." ${ }^{28}$ A partir destes elementos podemos inferir que as diferenças sociais não representavam obstáculos intransponíveis para o envolvimento de diferentes atores sociais na atividade de lazer proporcionada pelas salas de cinema. Os grupos menos privilegiados da sociedade criaram estratégias que possibilitavam sua inserção nesses espaços, pois, o escurinho do cinema igualava, pelo menos momentaneamente, os desiguais. ${ }^{29}$

Na interpretação de Sigrid, a sessão das 21 horas $^{30}$ era mais elitizada: "porque eu acho que [iam] as pessoas que moravam mais no centro... Aí não vinha gente dos bairros, porque não tinha ônibus tarde, né, e as pessoas da sessão das 9 (horas) moravam mais perto". ${ }^{31}$ Nessa fala identifica-se que havia a consciência das diferenças sociais dos atores que freqüentavam as salas de cinema. Nota-se que o outro é indicado como "gente dos bairros" em oposição aos "que moravam no centro", relacionando o status quo dos indivíduos com a localidade em que moravam.

$\mathrm{O}$ ato de ir ao cinema era um lazer cotidiano da sociedade de Novo Hamburgo. De acordo com as lembranças de Cláudio, o cinema fazia parte da rotina das pessoas, sendo que nos finais de semana concentravam as sessões mais aguardadas e concorridas.

O cinema... era um programa assim... evidente, óbvio nos sábados à noite. Novo Hamburgo tinha 4 cinemas, 1 em Hamburgo Velho, esse era meio que descarte, porque era raro eu ir lá. [...] E havia 3 no Centro de Novo Hamburgo e... e era comum a gente, no sábado à tarde, caminhar, passar no Centro, corria os 3 cinemas, olhava os cartazes e tomava a decisão. 'Hoje o filme que eu vou ver é este aí’. Isso era uma rotina bem comum, não era só eu, muitas pessoas faziam isso. ${ }^{32}$ 
Conforme Sigrid, "Em solteira nós íamos 3 a 4 vezes por semana. Porque não tinha outra coisa, né? Era o lazer que a gente tinha". ${ }^{33}$ Nesse caso, mais que uma opção de lazer em si, assistir a filmes nos cinemas representava, aparentemente, participar da vida social da cidade.

A ênfase da freqüência associada ao estado civil permite inferir que essa situação sofria alteração após o casamento. Contudo, esse aspecto parece não ter sido geral, pois, ao destacar a importância de ir ao cinema como um hábito em seu cotidiano, Hedviges aponta que estava no cinema quando entrou em trabalho de parto de três de suas quatro filhas.

Ah, tem um (filme) que me marcou muito, que eu não vi, só vi um pedaço, porque eu fui pro hospital ter a Simone (filha). Ela nasceu quando estava passando Laurence da Arábia. [...] Depois com a Daysi (outra filha), um filme de... faroeste. Nós íamos ao cinema adoidado! Aí também tive que sair... [...] e daí na outra noite o Inigo (marido) foi ver o resto pra me contar (risos)... Aí ele me contou. ${ }^{34}$

A depoente enfatiza o lugar ocupado pelo cinema em sua vida familiar ao relembrar os aspectos que compunham o período que precedia a sessão em si.

Essa época de 60 [...] não tinha muita opção, a única coisa eram os matinées que a gente ia às vezes. O cinema, né, cinema era muito... Bom, nós íamos quase todas as noites no Cinema. É... A gente não perdia um filme. Eu me lembro, isso eu me lembro. A vizinha ficava com as minhas crianças para a gente poder assistir um filme. [...] A gente tinha que parar na fila, comprava ingresso e ficava na fila, tanto é que o Lumière sempre tinha duas sessões, então a gente ia à sessão das 9 (horas), por exemplo, e às 7 horas nós já estávamos na fila, parado esperando lá na rua. Formava fila. ${ }^{35}$

As constantes e enormes filas antes das sessões foram aspectos enfatizados em muitas entrevistas. Para os depoentes, não havia incômodo em ficar aguardando por um longo tempo até poder entrar no cinema, visto que esse programa tinha uma grande relevância para seus freqüentadores, e também fazia parte de outro acontecimento socialmente tradicional, o footing, que ocorria nos finais de semana, antes e depois das sessões ao longo da Avenida Pedro Adams Filho. Esse programa, tipicamente jovem, incluía pequenos namoricos e flertes, quando as moças "desfilavam" na avenida sob o olhar atento dos rapazes, encostados nas paredes.

Outro programa característico da época eram as chamadas matinèes de domingos à tarde, que reuniam um grande número de pré-adolescentes para assistirem a uma sessão dupla de filmes. Nessa ocasião, era comum, aos meninos, 
chegarem antes das sessões e trocarem gibis e figurinhas. Cláudio comenta esse hábito:

\begin{abstract}
Em Novo Hamburgo, como em todo o Estado, havia um programa para pré-adolescentes em domingo à tarde, que era o matinée, que passavam dois filmes, nos 3 cinemas. Então era a mesma coisa, a gente percorria os 3 cinemas e escolhia os 2 filmes que a gente ia ver, que agradassem mais. Mesmo se o filme fosse meio ruim, nós íamos à matinée mesmo assim, carregando uma pilha de revistas em quadrinhos, gibis. A gente saía de casa à 1 da tarde, a sessão começava às 2 , e ia no mínimo até às 5 . Entre 1 e 2 (horas) da tarde a gente trocava revistas em quadrinhos. Isso era um programa de qualquer criança de 10, 11 anos. Era uma rotina. Era bom demais. ${ }^{36}$
\end{abstract}

A lembrança afetuosa do depoente expõe com nitidez o cinema como espaço de lazer e sociabilidade privilegiado na cidade, quando esse destaca que a qualidade do filme não era significativa para a decisão de freqüentar o cinema. ${ }^{37}$ As atividades precedentes e posteriores à projeção da película eram significativas, visto que, possibilitavam aos indivíduos interagirem socialmente, seja através do footing para os mais velhos ou do "comércio de gibis" para os jovens.

Nos anos 1960, os cinemas de "calçada" constituíam-se num dos principais espaços para a sociabilidade local, e os filmes eram a "vitrine" das novidades para a população jovem de Novo Hamburgo, influenciando profundamente o seu comportamento através de vestimentas, penteados, gírias, etc. Nas entrevistas, constatou-se a preocupação que os freqüentadores tinham em usar uma roupa apresentável para irem às sessões, de acordo com a moda e as tendências que os filmes mostravam, conforme relembra Sigrid,

A gente botava uma roupa de sair, roupa bonita, de festa. Não era calça jeans, nem tinha. Era roupa bonita, roupa de festa. A gente arrumava o cabelo especialmente para ir ao cinema. Os homens geralmente iam de fatiota, de terno. [...] A gente notava que as pessoas gostavam de imitar os cabelos das artistas, os comprimentos dos vestidos, até o penteado dos homens a gente notava. ${ }^{38}$

As salas de cinema configuravam-se, então, como espaços freqüentados para ver e ser visto, ou seja, locais em que o status social era constantemente enfatizado e as pessoas, de certa forma, zelavam pela ordem e pelo decoro. No entanto, as desordens nas sessões, apesar de pouco comuns, incomodavam os freqüentadores. Conforme uma nota do jornal NH: "Notamos a falta de decoro de certas pessoas nos cinemas locais. Alguns engraçadinhos, ignorando a boa ética social, se conduzem de maneira pouco recomendável e nada social. Para 
esses "astros" sem cultura, recomendamos algumas aulas noturnas [...]”39. Outra notícia reclamava dos desordeiros que prejudicavam as sessões de cinema, fazendo piadinhas a respeito do filme. "Chegará um dia em que um chefe de família não poderá mais levar seus filhos ao cinema, por causa dessas coisas feias que as pessoas falam.”40

Os entrevistadores disseram que, na maioria das vezes, os transtornos eram relacionados a pessoas que conversavam alto demais, que riam, gritavam ou brigavam, ou de casais de namorados que ultrapassavam as normas morais de conduta. Em seu depoimento Anny revelou que, juntamente com uma irmã e com uma amiga, gostava de incomodar os casaizinhos de namorados. "É que a gente gostava de furungar. Eles queriam se beijar e namorar no cinema e a gente não deixava, nós procurávamos sentar ali pra estorvar eles." ${ }^{41} \mathrm{O}$ entrevistado Paulo afirmou que, junto com alguns amigos, fazia umas "safadezas":

Nós comprávamos uns barbantes e enchíamos de enxofre (risos). Aí tocava um foguinho e punha embaixo do assento. Então dava uma clareira! Mas foi uma ou outra vez. Eles sabiam quem era. [...] E dentro do cinema a galera sempre gostava de zoar. Então nós íamos lá pra um cantinho e volta e meia os vovôs ‘Pshhhhh', já mandavam calar a boca. Principalmente aquelas propagandas (referindo-se aos anúncios antes dos filmes), as coisas que não interessam, e a gente ficava fazendo barulho. ${ }^{42}$

A análise do teor das reportagens do jornal em comparação com a fala dos depoentes permite observar as diferentes percepções dos atores sociais envolvidos no processo. No jornal a questão é apresentada com ênfase no problema moral inserido no contexto social, e que produz uma mácula na sociedade a ponto de referir que no futuro o cinema poderia deixar de ser uma atividade de lazer familiar. Já nos depoimentos daqueles que eram os jovens do período, a questão é minimizada e apresentada como uma travessura. Identifica-se, aparentemente, um conflito de gerações.

\section{TELINHA VERSUS TELONA}

Apesar da importância do cinema como lazer e espaço de sociabilidade, bem como da constituição do hábito de ir às salas de projeções, outros espaços passaram a se constituir na medida em que avanços tecnológicos foram inseridos na sociedade. Em seus estudos, Ramos (2000) destaca que o lazer se desenvolveu nas cidades rio-grandenses já no século XIX, também nos espaços privados das casas, "onde se recebia a elite local para saraus, ou sessões de canto, ou nos clubes, tanto da capital quanto do interior.” ${ }^{43}$ No século XX, houve "um notável 
desenvolvimento na área tecnológica do lazer, na qual despontaram, entre outros, o cinematógrafo, a fotografia, o rádio e o gramofone.”44 Para a autora,

O lazer é, portanto, a invenção dos usos do tempo disponível. Mas é no desdobramento da vida política e econômica que o lazer e a sociabilidade se apresentam. Eles são forma de representação das elites, funcionam como seu cartão de visitas e, embora possam ter nuanças locais, estão inscritos nos padrões ocidentais de representação dessa camada social. ${ }^{45}$

Nesse contexto, na década de 1960, começaram a surgir em Novo Hamburgo os primeiros aparelhos de televisão. Consistindo numa forma de lazer ainda muito sofisticado, esse "cinema caseiro" demorou um pouco a se popularizar na cidade, mas mesmo assim passou a interferir na freqüência das idas ao cinema de "calçada", pois se constituiu como um concorrente dele. Um dos fatores que contribuiu para a disseminação da compra das televisões foram as propagandas de lojas de eletrodomésticos que ofereciam, por exemplo, todo o material escolar para a criança cujos pais comprassem uma televisão no estabelecimento. ${ }^{46}$

Estabeleceu-se na cidade uma discussão que procurava destacar os prós e contras relativos à opção pela televisão e pelo cinema. Em crônica escrita por Lucia Alles ${ }^{47}$ vemos sua acirrada batalha contra a televisão e o seu posicionamento de não adquirir um aparelho até que a programação fosse de qualidade, porém, por pressão dos filhos ela diz: "acabei consentindo na compra do bicho". Em seguida ela chama a televisão de "a fera que nos está devorando a todos". Para acompanhar os filhos, a escritora confessava que começou a ver os programas e admitiu que mesmo depois que as crianças tivessem ido para a cama, ela e o marido continuavam a ver televisão. Seguindo a crônica: "mas foi no inverno que o monstro nos tragou: o tricot rendia que era uma beleza [e] a facilidade de desligar a qualquer momento [...]." 48

Por outro lado, Lucia, em defesa de sua dignidade ressaltou: "não desci aos shows de gosto mais que duvidoso, ao dramalhão das novelas, nem a calamidade dos shows humorísticos". Por último ela admite que o cinema "acalenta o espírito, pois é muito bom sentir que nem só de pão vive o homem”. ${ }^{49}$ Com essa última frase é visualizada a importância do cinema como atividade de lazer e o fascínio dos filmes, que permitiam o direito de sonhar. A questão da TV mostra o crescimento econômico e acesso a novas tecnologias. Quando Lúcia diz que o cinema colabora com o espírito e mostra que o homem não vive só de pão, mas de fantasias, ela se refere à cultura do trabalho, tão forte e fundadora da cidade.

Considerando premissas outras, Turner (1997), ${ }^{50}$ na sua obra intitulada "O cinema como prática social”, acredita que a dificuldade da indústria cinemato- 
gráfica e o domínio dos filmes americanos iniciam a queda de audiência das salas, pois nos anos 70 aumentaram as opções de lazer. E o movimento tanto no exterior quanto no Brasil foram o aumento dos serviços voltados para os lares televisão a cabo, computadores, videogames - e com o aumento da mobilidade da população resultante de um número maior de veículos particulares, aumentando as opções de lazer para os indivíduos de todas as camadas.

De acordo com as matérias jornalísticas, a influência da televisão foi aumentando constantemente. Uma matéria do jornal NH em 1969 questionava: "O cinema está em decadência?" ${ }^{1} \mathrm{Na}$ ocasião, foram entrevistados gerentes dos cinemas locais e estes afirmaram que a freqüência vinha caindo já desde meados da década de 1960. Dorival Villanova, sócio-gerente do Cine Lumière na época, apontava que a comodidade que a televisão gerava - em não ter de sair de casa -, poderia ser entendida como uma das razões que teria motivado a baixa de freqüência ao cinema. Outro fator explicativo poderia estar no baixo poder aquisitivo, visto que: " $80 \%$ do público pertence à classe operária e não pode ir ao cinema muitas vezes por semana." 52 Para Rubem, gerente do Cine Avenida, a menor freqüência ao cinema se devia a falta de dinheiro do público:

Quem vai ao cinema é a pessoa de classe média para baixo, em geral. Esse também, via de regra, não tem TV. Além disso, o número de aparelhos de televisão na cidade é relativamente baixo para o número de habitantes. Em junho de 1968 havia 5.800 aparelhos na cidade. Esse número deve ter subido para 8 ou 9 mil hoje. A cidade possui 80 mil habitantes, mais ou menos. A televisão poderá influir um pouco na ausência de senhoras no cinema. Mas o homem, que costuma ir ao cinema em dias de semana, não deixa de sair por causa da TV..$^{53}$

De acordo com Malverdes (2008), que fez um estudo semelhante na grande Vitória no Espírito Santo, ${ }^{54}$ essa impressão destacada por Dorival era percepção de um movimento que estava ocorrendo em todo o Brasil, devido à falta de público. Gatti (2000) ${ }^{55}$ cita que tenham fechado 1.200 salas em todo o Brasil nessa época, e que a queda continuou entre os anos de 1979 e 1981 quando o público diminuiu 34\%, ou seja, de 192 milhões para 139 milhões, em seguida todos os números referentes ao cinema entraram, pela análise do autor, em queda livre.

Essa conjuntura se reflete na percepção do gerente quando, no discurso, destaca que o público "é a pessoa de classe média para baixo", deixando transparecer que, nesse momento, o grupo considerado de elite da cidade não freqüentava mais, de forma assídua, as salas de cinema. Outro aspecto significativo enfocado por Rubem é a referência à ausência das senhoras. Essa questão remete ao depoimento de Sigrid, anteriormente citado, quando ela lembrou que freqüentava o cinema assiduamente antes do casamento. Nesse sentido, podemos 
inferir que a partir do matrimônio e com a existência da televisão, o cinema entendido como espaço de sociabilidade e lazer restringiu-se para uma parcela do público feminino.

A mesma reportagem se refere às dificuldades quanto à montagem da programação dos filmes pelos exibidores, pois esses dependiam das companhias de distribuição. Assim, o exibidor não podia escolher entre os filmes que os distribuidores tinham, os que lhe dariam maior lucro ou que seriam mais bem aceitos pelo público, mas levar um "pacote" contendo, inclusive, filmes pouco lucrativos. Além disso, existia uma relativa concorrência entre cinemas, que disputavam os melhores filmes e os preços cobrados pelas distribuidoras, que sofriam altas constantes.

Paulatinamente, o periódico local divulgava a máxima de que a televisão "invadia" os lares hamburguenses e causava deslumbramento, como podemos ver na crônica de Lauro Diogo de Jesus,

[...] a televisão é algo assim do outro mundo. Um negócio de louco, para falar a verdade. Quando estou assistindo o Jornal Nacional e vejo, imagem e som, dos mais distantes recantos do Brasil, não consigo esconder minha admiração pela inteligência do bicho homem. ${ }^{56}$

Para nossos depoentes, a influência da televisão também não passou despercebida, apesar da telona não ter sido trocada pela telinha subitamente, conforme destaca Hedviges,

[...] nós tínhamos televisão, mas ainda continuávamos indo ao cinema, não tão seguido como nós íamos antes, a gente assistia mais na televisão, apesar de que tinha só 3 canais. Então se via às vezes uma novela... Filmes, como têm hoje em dia, não havia tantos canais, então a televisão sempre ficava na sala e toda a família sentava ao redor da televisão. ${ }^{57}$

Essas fontes dão conta de uma perspectiva que entende que a televisão vai concentrando a atenção de toda a família ao seu redor e encanta a partir de uma programação que tornou-se diversificada e atrativa, ou seja, a mulher atraída pelas novelas, as crianças pelos seriados de super-heróis que começaram a ser veiculados, e por fim os homens, na fala de Cláudio, “a televisão tinha um conforto imbatível"58 e segundo Sigrid, "tinha o lazer em casa, né. Antigamente não, tinha que ir ao cinema pra se distrair."59

Os cinemas, no entanto, buscavam investir em inovações para seu público na tentativa de atrair os freqüentadores que, paulatinamente, se ausentavam seduzidos pelas facilidades oferecidas pela televisão. Em 1969 e 1970, os cinemas Avenida e Saionara receberam reformas, implantando o som estereofônico e a 
projeção de $70 \mathrm{~mm}$, novidades na época juntamente com novas cadeiras e um "hall" de entrada maior e mais luxuoso. Esse fato foi amplamente divulgado na imprensa ${ }^{60}$ Além disso, incluíram matinèes em todas as tardes, visando atrair o público infantil. "É uma boa pedida para os dias de férias, em tardes de 'nada para fazer." " 61 No entanto, nem tudo contentava a população que, tendo outras opções de lazer, passou a observar aspectos, antes pouco considerados, relacionados ao conforto, como podemos observar na carta do leitor do Jornal NH:

Um recado ao sr João Scherer, gerente do Cine Avenida: apesar daquela casa apresentar a maioria dos bons espetáculos cinematográficos de nossa cidade, o calor incrível que lá existe está a ponto de afugentar os espectadores. Os ventiladores não resolvem nada, deve se tentar uma nova solução. ${ }^{62}$

Foi nesse mesmo período - fins dos anos sessenta e início dos anos setenta - que os eventos relacionados ao cinema, publicados no Jornal NH, atingiram o maior número entre todos os anos analisados. As colunas de programação, notícias vinculadas a filmes, diretores, atores e atrizes nacionais e internacionais foram intensificadas - e, associadas às notícias sobre música e televisão - dominando as pautas sobre cultura no jornal a partir do final da década de 1970 .

Nesse contexto o Cine Aída, de Hamburgo Velho, que iniciou suas atividades no início do século XX, foi fechado no ano de 1976. O principal motivo alegado pelos proprietários foi o não atendimento ao pedido de redução de impostos feito à municipalidade. Em virtude disso, os proprietários optaram por fechar a casa. Segundo o gerente Arlindo Sperb: "Já desde a fundação do cinema, o pessoal de Hamburgo Velho não ia muito lá, eles gostavam mais de vir ao cinema no centro, pois aí aproveitavam para dar um passeio.”63 Essa percepção foi confirmada pelos depoentes, pois a maioria afirmou que nunca freqüentou o referido cinema.

Com as dificuldades financeiras, os cinemas apelaram para a sonegação, reutilizando bilhetes para não pagarem tantos impostos. Além disso, a qualidade dos filmes e das cópias passou a decrescer. Trazer películas boas custava caro e as cópias também deixavam a desejar: "Os filmes arrebentam durante a projeção porque as cópias no Brasil são poucas, e passam por todos os cinemas, chegando a um desgaste muito grande.” ${ }^{4}$ Os espectadores também reclamavam: "Dificilmente recebemos aqui filmes realmente bons, na maioria das vezes eles chegam com atraso em relação a outras cidades, principalmente Porto Alegre.”65

No período em que o cinema Aída encerrava suas atividades, já se prenunciava o fechamento das outras salas. Em 1982, o jornal NH noticiava que a cidade estava perdendo um pedaço de sua história, pois o grandioso Cine Lumière que fora palco de filmes épicos e também convivera com o período fértil do cinema nacional, passando até a fase da pornochanchada, dos filmes de Teixeiri- 
nha, que garantiam casa cheia, e de alguns clássicos importantes - realizou sua última sessão. ${ }^{66}$

Representantes da classe artística local e moradores mais antigos lamentaram o fim da "troca de revistas, de figurinhas, o namorico dos adolescentes, além de tudo o que representa uma casa de espetáculo, foram formando dentro de cada um aquele amor profundo pelo Lumière.” ${ }^{\prime 77} \mathrm{O}$ cronista Alceu Feijó enfatizou, nostalgicamente, o fechamento do cinema, que seria substituído por uma loja de eletrodomésticos.

Terminou o ponto de encontro dos namoradinhos das matinês e das sessões mais comprometedoras da noite. [...] Lumière, onde os suspiros arrebatados dos namorados serão substituídos pela expectativa dos balconistas no afã de aumentar seus rendimentos. O escurinho conivente com os namorados será desvendado por potentes conjuntos luminosos. A poesia dará lugar ao prosaico, os heróis abandonarão a tela para sempre. ${ }^{68}$

Destaca-se no discurso a percepção da perda, da criação de um vácuo no espaço das práticas sociais. Mais do que a substituição de um tipo de lazer por outro, o fechamento de um cinema como o Lumière é expresso, na fala do cronista, como a finalização de um tempo, um marco divisor de possibilidades de sociabilidade na cidade.

\section{“ILHA DE CONSUMO NO CORAÇÃO DA CIDADE” 69}

Neste período entre o final da década de 1980 e o início dos anos 1990, a cidade de Novo Hamburgo aguardava o término das obras de seu shopping center, cujo projeto e execução se arrastavam desde o início dos anos oitenta devido a aspectos, tais como, modificações do projeto, falência da incorporadora, venda para outro grupo empresarial disposto a levar a cabo as obras, etc. A prefeitura e a comunidade pressionavam para a inauguração - São Leopoldo, cidade vizinha, começara a construir seu shopping bem depois e já o tinha funcionando -, enquanto que os chargistas locais aproveitavam para fazer piada, chamando o prédio de elefante branco, lesma, caixa-forte do Tio Patinhas. ${ }^{70}$

Em outubro de 1991, o shopping center foi finalmente inaugurado. Com 20 milhões de dólares investidos, o local abrigaria 140 lojas, 14 restaurantes, 2 cinemas, 5 escadas rolantes, 2 sanitários por pavimento, sistema de proteção automática contra incêndio, calefação interna, oferecendo assim um ambiente agradável com variada opção de compra, aliado à segurança e conforto. Os administradores esperavam vendas três ou quatro vezes maiores do que no comércio tradicional, uma vez que as vitrinas seriam vistas por um número maior de possíveis consumidores. ${ }^{71}$ 
A ilha de consumo da cidade havia se tornado realidade. Aqueles que desde os anos oitenta se aglomeravam junto ao vidro da porta principal, tentando ver o que estava sendo feito no prédio ainda em construção, agora queriam ir ao shopping center para ver as novidades: valia a pena até fazer fila para andar de escada rolante. ${ }^{72}$ Conforme Selbach (1999):

Com a abertura, a população acorreu em massa; todos queiram ver a grandiosa obra que tinha despertado tanta curiosidade durante tantos anos. Lá dentro, o ambiente era um mundo completo de sonhos e fantasias: lojas com vitrinas espetaculares, decoração sem precedentes, nada de calor ou frio, nem mendigos ou ladrões, etc. O local era perfeito para passear com a família, flertar para futuros encontros, conversar com amigos... O Shopping deveria ser o espaço da comunidade, mas não de todos, e sim daqueles que iriam ali para gastar. ${ }^{73}$

Segurança, comodidade, facilidade: era tudo que o estilo de vida do final do século ditava e que espaços como os shopping centers proporcionavam. Com uma infra-estrutura minuciosamente planejada, um ambiente sóbrio e acolhedor, galerias e lojas climatizadas e amplas para evitar o acúmulo de pessoas, sonorização ambiental, piso de mármore, escadas rolantes, áreas de descanso e lazer, fraldários, berçários, banheiros com mictórios limpos, etc., tudo era feito para fazer do local um espaço não só de compras, mas de sociabilidade geral, longe do caos urbano do centro da cidade.

O shopping era a nova "coqueluche da cidade", consolidando, acima de tudo, o lazer consumista:

Definido como um centro de consumo nos tempos atuais, o shopping center passou a conceituar progresso urbano e modernidade. E nessa estratégia comercial eles cada vez mais conquistam seu espaço. Nestes locais a ordem é consumir, o que também passou a ser uma referência contemporânea para lazer. E a forma é das mais tentadoras, pois num único local reúnem-se lojas com múltiplas opções de compra. Também o paladar é despertado com as lanchonetes e restaurantes nas já afanadas praças de fast food... Com estacionamentos fechados e seguros, as pessoas saem de seus carros tendo à sua frente todas as coisas que necessitam e longe dos centros urbanos onde menores abandonados, vendedores ambulantes e, por vezes, assaltantes fazem a mescla da definida "massa social”. No shopping, o público/ freguês diverte-se com as escadas rolantes, sonha com o colorido das vitrines e anseia pelo belo produto estampado... A modernidade nas vendas é revestida de neon, música das paradas de sucesso e muitos 
multicolores apelos. Se os anseios mais profundos de cada um não podem ser resolvidos, a satisfação pode ser aliviada através de um sanduíche, uma comprinha, ou um flerte em meio a tantas e belas vitrines. É a geração shopping center. ${ }^{74}$

Apesar de todos os problemas em sua fase de concretização, e da desconfiança de alguns quanto ao modo padrão de comportamento que ditava, o Novo Shopping foi um grande sucesso se considerarmos que, em 1993, dois anos depois de sua abertura, este se consolidava como o maior centro de compras da região, com 124 lojas e a circulação de cerca de 20 mil pessoas diariamente - 35 mil nas sextas e sábados. ${ }^{75}$

Enquanto o shopping center atraía todos os olhares e carteiras, os cinemas de "calçada" iam sendo esquecidos. No final da década de 1980, o Cinema Avenida encerrou suas atividades, restando então apenas o Cine Saionara como modelo dos grandes "cinemões". ${ }^{76}$

José Carlos (Zeca) Blankenheim, na época a frente do Saionara junto de seu irmão Luís Henrique, consideravam que estava "ocorrendo uma melhoria da qualidade das salas, em detrimento da quantidade de cinemas. Os cinemas estão indo para os shoppings. O conforto das salas e a melhor qualidade de som e imagem deram um novo impulso ao cinema”. ${ }^{77}$ O Cine Saionara sofria com a ausência de público: "O valor histórico é algo bonito para visitar, mas não para assistir filme todo dia. Não adianta ter coisa bonita que não funciona."78

Diante disso, os proprietários resolveram acompanhar a tendência e garantir um espaço para o cinema no shopping da cidade, que no período da inauguração contava com duas salas: Novo Cine 1 e 2. A tendência foi a redução no tamanho das salas, pois, enquanto o grandioso Cine Saionara foi construído para abrigar 700 pessoas, as duas salas do Novo Cine foram inauguradas com 310 e 160 lugares, respectivamente.

Nessa época [início dos anos 90], quando eu estava nos Estados Unidos, eu vi que cinema só tinha em shopping center. E shopping center não existia aqui no Rio Grande do Sul. Pra ter uma idéia, tinha o Iguatemi, que não tinha cinema, depois foi ter. Novo Hamburgo não tinha shopping, o Praia de Belas abriu uma semana depois do shopping daqui. São Leopoldo tinha um shopping assim, uma galeria. Era uma coisa muito embrionária. Então quando eu voltei dos EUA eu disse: 'cinema é em shopping center’. E aí, vamos fazer ou não, o pessoal achava que era inviável. Parecia que era uma coisa muito cara. Porque o cinema de rua tinha um formato, e o shopping já tinha um formato diferente, sessões o dia inteiro. Eram menores, outra qualidade. ${ }^{79}$ 
As transformações promovidas no conjunto social a partir da perspectiva econômica de progresso urbano afetaram, igualmente, a perspectiva do lazer, conforme podemos observar no depoimento. A compreensão do shopping como um espaço de consumo, de lazer e de sociabilidade privilegiada promoveu o desprestígio da rua e, consequentemente, do cinema de calçada. Assim, a migração e adaptação das salas de projeção da rua para o espaço fechado dos shoppings acompanharam a tendência da sociedade local que, espelhada em modelos internacionais macros, percebia a inovação como progresso.

Nessa perspectiva, concomitante a prosperidade das salas do shopping, deu-se a marginalização das antigas salas localizadas no centro da cidade, que passaram a atender um público específico, formado predominantemente por indivíduos que buscavam os filmes pornográficos ou então, nos finais de semana, por casais em busca de espaço reservado para namorar. Em 1995, o Cine Saionara, antigo Cine Theatro Carlos Gomes, inaugurado em 1930, encerrou suas atividades. ${ }^{80}$ Dois anos depois, o prédio amanheceu com uma faixa: "Breve aqui, Igreja Universal do Reino de Deus," ${ }^{81}$ tendo o mesmo fim que o cine Aída, de Hamburgo Velho, duas décadas antes. Quanto aos cinemas do shopping, segundo o Jornal $\mathrm{NH}$, tornou-se local privilegiado pelos adolescentes que, para a tranqüilidade dos pais, podiam usufruir de múltiplas formas de lazer e de práticas de sociabilidade em segurança. ${ }^{82}$

\section{CONSIDERAÇÕES FINAIS}

Em relação às categorias que elegemos para essa análise - lazer, sociabilidade e memória -, e de acordo com a metodologia e os objetos de estudo - o jornal NH e as entrevistas de história oral - podemos tecer algumas considerações.

O clima de nostalgia pelo fim dos cinemas de "calçada" contagiou os mais antigos, que não se adaptaram às mudanças.

O cinema era um rito programado. Hoje, ir à sala exibidora tornou-se uma extensão das compras nos shoppings. Antigamente, uma hora antes o cinéfilo tomava banho, vestia-se, penteava-se, raspava a barba, calçava o sapato e, pronto e arrumado, saia de casa em direção ao cinema. Existia um clima, uma atmosfera, uma comunhão. Já na poltrona, dava para ouvir uma música ao fundo e, de repente, o gongo anunciando o início da sessão; luzes coloridas se alternavam no ritmo da batida do gongo e a cortina abria-se, estampando na tela o cine-jornal com as notícias de 4 meses atrás. Hoje, vai-se primeiro ao shopping e o cinema é mera extensão do shoppiar ${ }^{83}$ 
Nas palavras de José Carlos Blankenheim, “as pessoas dizem 'ah, muito legal, me lembro como o cinema era’. Só que as pessoas têm as lembranças de quando estavam naquele contexto. [...] As pessoas têm aquela idéia do saudosismo.” Para o depoente, o período dos cinemas de "calçada” foi inesquecível, porém, deve ser valorizado na conjuntura em que ocorreu e não lembrado através de juízos de valor, como melhor ou mais bonito. No entanto, a memória evocada pela história oral não estabelece uma ruptura entre o passado e o presente, conforme afirma Halbwachs (2006). Dessa forma, os depoentes sentiram a perda desses espaços tão importantes de suas juventudes, pois o significado destes perdeu-se junto com estes cinemas que iam fechando:

Então a gente... ia ao cinema, né. Ia com as amigas, ou... pra distrair tinha que ir ao cinema. [...] Pra se encontrar e tudo. Agora, por exemplo, eu estou hã, não sei qual é o último filme que eu vi. [...] Eu não sei quantos anos faz que eu não vou no cinema! Não fui mais ao cinema! E por causa da televisão. Porque agora a gente escolhe os filmes, né, tem sempre um filme bom pra assistir. E daí a gente acabou não indo mais no cinema. [...] A gente tinha escolha, podia escolher. E depois começaram a fechar (os cinemas) e agora eu acho que as pessoas que querem assistir a um filme vão a Canoas, Porto Alegre, porque aqui, agora, nós não temos mais cinema. Tem só o Shopping ${ }^{84}$

É interessante notar que, para a depoente, as percepções sobre "ir ao cinema” se modificaram completamente, a ponto de não mais reconhecer no shopping o programa que fazia décadas atrás. Ou seja, sua memória estava intimamente ligada aos lugares em que esta estava vinculada, e, quando esse local desaparece, as recordações a ele relacionadas tendem a deixar de ter o mesmo significado. Dessa forma, a memória retém do passado apenas o que está vivo ou "capaz de viver na consciência do grupo que a mantém". ${ }^{85} \mathrm{~A}$ esse processo de constituição da memória, Pollak (1992) chama de enquadramento da memória, que envolve "um trabalho de manutenção, de coerência, de unidade, de continuidade, de organização."

Percebemos, também, ao longo das entrevistas realizadas que há muitos pontos em comum nas falas dos entrevistados, ou seja, pontos de saturação, em que os discursos se repetiram, enfatizando as mesmas características: a importância do ato de "ir ao cinema" como uma atividade de lazer e o cinema como um espaço de sociabilidade, a influência da televisão para a queda de freqüência do público nas sessões e a relação que as memórias individuais dos depoentes estabeleceram com uma memória coletiva, uma vez que estas foram evocadas a partir de suas relações com grupos, os quais estabeleciam laços identitários, de acordo com as premissas de Halbwachs (2006) e Pollak (1992). 
Foi comum os entrevistados utilizarem durante sua entrevista a primeira pessoa do plural, o “nós”, admitindo a ligação de suas lembranças com outras, de familiares, amigos de infância, cônjuges, etc., significativamente essa questão remete-nos à Pollak (1992), que, apoiando-se nos estudos de Halbwachs e Pierre Nora, afirma que a memória é essencial a um grupo na medida em que é um elemento constituinte do sentimento de identidade, tanto individual como coletiva. ${ }^{87}$ Para o autor, a memória e a identidade são valores em permanente conflito, pois objetivam o reconhecimento de uma interpretação do passado, constantemente alterada pelo presente.

Durante as quatro décadas que analisamos o cinema, inúmeras foram as transformações nas tecnologias que, gradativamente, foram se popularizando e alterando as formas de lazer e sociabilidade dos indivíduos: a televisão, nos anos 1970, o videocassete, nos anos 1980, a televisão por assinatura, os computadores pessoais e a internet, na década de 1990. Todas essas mudanças refletiram em alterações nas relações sociais e nas formas de manifestação acerca do lazer e da sociabilidade por parte da população de Novo Hamburgo.

As pessoas se encontravam no cinema. O pessoal ia lá, conhecia amigos, namorados. Depois, quando veio o shopping, mudou, mas antes disso, era ali que as coisas aconteciam. Todos os domingos as pessoas iam ao cinema, não interessava o filme, porque era um lugar seguro, um lugar ideal para se fazer as amizades nessa faixa etária, entre a infância e a idade adulta. Então muita gente passou por ali. ${ }^{88}$

Esse contexto foi influenciado por uma tendência mundial de privatização do cotidiano. As pessoas deixaram de freqüentar muitos locais públicos nas grandes cidades devido a questões que o próprio crescimento das mesmas provocou: mais violência, crescimento urbano intenso que tornou as regiões centrais das cidades, de certa forma, obsoletas, servindo unicamente ao comércio e não à moradia ou às práticas de lazer. As ruas, de uma maneira geral, deixaram gradualmente - entre o final da década de 1960 e o início da década de 1970 - de ser o ponto de encontro público por excelência para transformarem-se em vias expressas de deslocamento desenfreado de veículos e pessoas cada vez mais apressadas, ou seja, marcadas pela impessoalidade. ${ }^{89}$

A lógica capitalista do mercado impôs aos cinemas de "calçada” alterações que estes não puderam realizar, pois estavam inseridas em espaços que pouco a pouco também foram se degradando. As fábricas de sonhos fecharam nas calçadas e se mudaram para a impessoalidade dos shopping centers. No entanto, a própria temporalidade se incumbirá de alterar essa memória, pois, conforme afirma Zanella (2006) 
[...] talvez, para as gerações futuras, o espaço impreciso e despersonalizado dos shoppings centers tenha significação e importância semelhante a que os centros históricos das cidades tiveram para as gerações passadas e presentes. Afinal, só o tempo tem o poder de delegar representatividade/memória a determinação espaço físico, mesmo que este esteja identificado com a pós-modernidade. E, com as salas de cinema, hoje localizadas nos shoppings centers, não será diferente. ${ }^{90}$

As salas de cinema, desde os chamados cinemas de "calçada" até as salas de exibição nos shopping centers, representam importantes opções de lazer e espaços de sociabilidade. O lazer e a sociabilidade tiveram - e ainda tem - no cinema um grande "palco" para sua manifestação, um local onde as relações sociais eram e são estreitadas continuamente e o status adquiriu considerável importância através do consumo de massa do espetáculo cinematográfico, afetando modos de ser, de pensar, de vestir e de agir dos sujeitos envolvidos.

Ao observarmos os discursos dos depoentes, para os quais o cinema antigo, numa representação saudosista, expressa símbolos de valor inerente a um período existente na memória, reportamos as concepções de Malverdes (2008) quando este aponta que o espetáculo cinematográfico chegou ao fim na acepção antiga da questão, porém, a emoção de ir ao cinema se transformou com o novo contexto, não é mais somente um acontecimento social e sim faz parte das cidades, sendo ainda considerado uma das atrações mais populares. Para o autor é importante considerar que as cidades não são mais tão glamourosas, apresentam no seu dia-a-dia problemas como, por exemplo, o trânsito caótico, a violência desenfreada e as restrições de estacionamento.

Não se trata de nostalgia, mas de entender que os cinemas, mais do que meras formas de entretenimento, foram personagens referenciais para a estrutura urbana das cidades e para as relações sociais e culturais de seus habitantes. As transformações ao longo do tempo (re) significaram, no escurinho do cine$m a$, as percepções e os comportamentos dos atores sociais, conforme pudemos observar através nas matérias de jornal analisadas e de acordo com a memória de seus freqüentadores.

\section{REFERÊNCIAS E NOTAS:}

\section{DEPOIMENTOS:}

BACKES, Verena. Verena Backes: depoimento: [jun. 2008]. Entrevistadores: C. E. Ströher e V. F. Schilling. Novo Hamburgo: Centro Universitário Feevale, 2008. 1 fita cassete (90 min). Entrevista cedida ao projeto “O doce nada fazer”: um estudo sobre lazer e identidade(s) em Novo Hamburgo. 
BLANKENHEIM, José Carlos. José Carlos Blankenheim: depoimento: [abr. 2008]. Entrevistadores: C. E. Ströher e V. F. Schilling. Novo Hamburgo: Centro Universitário Feevale, 2008. 1 fita cassete (90 min). Entrevista cedida ao projeto "O doce nada fazer": um estudo sobre lazer e identidade(s) em Novo Hamburgo.

BENDER, Cláudio Luiz. Cláudio Luiz Bender: depoimento: [mai. 2008]. Entrevistadores: C. E. Ströher e V. F. Schilling. Novo Hamburgo: Centro Universitário Feevale, 2008. 1 fita cassete $(90 \mathrm{~min})$. Entrevista cedida ao projeto "O doce nada fazer”: um estudo sobre lazer e identidade(s) em Novo Hamburgo.

ENGELMANN, Anny Bertrudes. Anny Bertrudes Engelmann: depoimento: [mar. 2008]. Entrevistadores: C. E. Ströher e V. F. Schilling. Novo Hamburgo: Centro Universitário Feevale, 2008. 1 fita cassete (90 min). Entrevista cedida ao projeto “O doce nada fazer”: um estudo sobre lazer e identidade(s) em Novo Hamburgo.

FISCHER, Hedviges Terezinha Erkens. Hedviges Terezinha Erkens Fischer: depoimento: [mar. 2008]. Entrevistadores: C. E. Ströher e V. F. Schilling. Novo Hamburgo: Centro Universitário Feevale, 2008. 1 fita cassete (90 min). Entrevista cedida ao projeto "O doce nada fazer": um estudo sobre lazer e identidade(s) em Novo Hamburgo.

SCHILLING, Sigrid Esther. Sigrid Esther Schilling: depoimento: [mar. 2008]. Entrevistadores: C. E. Ströher e V. F. Schilling. Novo Hamburgo: Centro Universitário Feevale, 2008. 1 fita cassete (90 min). Entrevista cedida ao projeto "O doce nada fazer”: um estudo sobre lazer e identidade(s) em Novo Hamburgo.

REICHERT, Paulo. Paulo Reichert: depoimento: [mai. 2008]. Entrevistadores: C. E. Ströher e V. F. Schilling. Novo Hamburgo: Centro Universitário Feevale, 2008. 2 fitas cassete (90 min). Entrevista cedida ao projeto "O doce nada fazer": um estudo sobre lazer e identidade(s) em Novo Hamburgo.

\section{NOTAS}

\footnotetext{
2 Um dos objetivos do projeto é analisar de que forma se deu a construção das diferentes identidades dos grupos sociais de Novo Hamburgo através das formas de lazer realizadas no século XX e como a população local percebia os eventos de lazer - na qual as atividades relacionadas ao cinema exerceram grande importância - e de que forma se apropriavam de seus fazeres.

${ }^{3} \mathrm{O}$ Grupo destaca como seus preceitos norteadores o pioneirismo e o direcionamento para uma cobertura regional e, como missão manifesta, o compromisso de informar com independência, exatidão e respeito ao cidadão, bem como envolver-se e estimular o desenvolvimento das comunidades e dos setores onde atua.
} 
${ }^{4}$ BARDIN, Laurence. Análise de conteúdo. Lisboa: Edições 70, 1977, p. 31.

5lbidem, p. 29.

${ }^{6}$ Ibidem, p. 36-37.

7 ALBERTI, Verena. Fontes orais: Histórias dentro da História. In: PINSKY, Carla Bassanezi (org). Fontes históricas. São Paulo: Contexto, 2005, p. 155.

8 Ibidem, p. 164.

${ }^{9}$ Ibidem, p. 167.

10 GOMES, Paulo Emílio Sales. Cinema Trajetória no subdesenvolvimento. São Paulo: Paz e Terra, 1996.

" $O$ interesse que o cinema desperta na sociedade gerou uma ampla e diversificada historiografia que conta com múltiplas abordagens, como exemplo, destacamos o estudo analítico e questionador sobre a história do cinema no Brasil de: BERNARDET, Jean-Claude. Historiografia Clássica do Cinema Brasileiro. São Paulo: Annablume, 1995. Que postula a crença de que os estudos sobre cinema devem contemplar a complexa máquina internacional da indústria cinematográfica, do comércio, do controle e do poder de infiltração da cultura. Outros estudos foram desenvolvidos focando regiões e cidades, que discutem as suas histórias pelo cinema e através dele, assim como questionam o fim dos chamados cinemas de calçada. $O$ cinema também permite outras abordagens como questões urbanísticas e territoriais, ou ainda estudos sociológicos sobre a sociabilidade do público nas salas, considerando temáticas como prostituição e pornografia - VALE, Alexandre F. Câmara. No escurinho do cinema: cenas de um público implícito. São Paulo: Annablume, 2000. - entre outros.

12 Sessões históricas no início do século. Jornal NH. Novo Hamburgo, 04/02/2000, p. 4.

${ }^{13}$ FLORES, Adriano. O que passa com os cinemas. Jornal NH, Novo Hamburgo, 23 e 24 julh. 1994. Caderno de Domingo, Capa, p. 4 e 5.

${ }^{14} \mathrm{O}$ crescimento econômico da cidade foi marcado e potencializado pela instalação de uma estrada de ferro, em 1874, que ligava a então colônia de Hamburger Berg com a capital da província, Porto Alegre. $\bigcirc$ trabalho artesanal dos imigrantes de origem germânica e a existência de matérias-primas como o couro e seus derivados, permitiu o desenvolvimento da indústria coureiro-calçadista. No início do século $X X$, Novo Hamburgo era um dos distritos de São Leopoldo, porém seu desenvolvimento comercial e industrial fez crescer a idéia de emancipação, que foi concretizada em 05 de abril de 1927.

${ }^{15}$ Entrevista com José Carlos Blankenheim. Abril de 2008.

${ }^{16}$ DUMAZEDIER, Joffre. Sociologia Empírica do Lazer. São Paulo: Perspectiva, 1979, p. 94..

${ }^{17}$ Apud RAMOS, 2000, p. 7

18 SIMMEL, Georg. Questões fundamentais da sociologia. Rio de Janeiro: Jorge Ed., 2006, p. 65.

${ }^{19}$ Ibidem, p. 7I.

20 HALBWACHS, Maurice. A Memória Coletiva. São Paulo: Centauro, 2006, p. 39.

${ }^{21}$ Ibidem, p. 66-67.

22 SELBACH, Jefferson Francisco. Novo Hamburgo 1927-1997: os espaços de sociabilidade na gangorra da modernidade. 1999. 416 f.. Dissertação (Mestrado em Planejamento Urbano e Regional) - Faculdade de Arquitetura, Universidade Federal do Rio Grande do Sul, Porto Alegre, 1999.

${ }^{23}$ BENJAMIN, Walter. A obra de arte na era da reprodutibilidade técnica. In:

I, p. 179. Apud SELBACH, 1999, p. 122. (?)

${ }^{24}$ DUMAZEDIER, op. cit., p. 28.

${ }^{25}$ Entrevista com Verena Backes. Junho de 2008.

${ }^{26}$ Entrevista com Hedviges Terezinha Erkens Fischer. Março de 2008.

27 Entrevista com Paulo Reichert. Maio de 2008.

${ }^{28}$ Segundo Selbach (2006, p. 298 [se é uma paráfrase não precisa colocar a página, caso seja uma citação direta colocar aspas]), a Rua Oswaldo Cruz era, já antes da década de 1950, conhecida por Rua da Limpeza, pois era neste local onde eram destinados o lixo e os detritos necessários para a conservação do asseio dentro da cidade. Com o progresso de Novo Hamburgo, a zona circunvizinha transformou-se em florescente e populoso bairro, onde as exalações dos dias de mormaço se tornavam insuportáveis. Assim, por constituir-se uma área periférica, invariavelmente era caracterizada por ser habitada por negros e pobres, pois, no período, a área urbana valorizada restringia-se ao centro da 
cidade e ao bairro Hamburgo Velho, de população predominantemente de origem germânica.

29 Magalhães (2008), ao analisar as crônicas e notas da imprensa hamburguense em relação aos negros nos anos 1930, destaca que o local imposto a estes nos cinemas era chamado vulgarmente de "poleiro" e que, em virtude dessa discriminação, os negros pleitearam preços mais justos e acessíveis para o espaço determinado.

${ }^{30}$ Nos anos 1960, os cinemas apresentavam normalmente duas sessões diárias, sendo uma às 19 horas e a outra às 21 horas, conforme a duração das películas.

31 Entrevista com Sigrid Esther Shilling. Março de 2008.

32 Entrevista com Cláudio Luiz Bender. Maio de 2008.

${ }^{33}$ Entrevista com Sigrid Esther Shilling. Março de 2008.

${ }^{34}$ Entrevista com Hedviges Terezinha Erkens Fischer. Março de 2008.

35 Ibidem.

${ }^{36}$ Entrevista com Cláudio Luiz Bender. Maio de 2008.

${ }^{37}$ Quanto aos gêneros preferidos dos freqüentadores de cinema na década de 1960, estes variavam entre os românticos e épicos para as moças, e de faroeste, para os rapazes. Para as crianças e os préadolescentes, os favoritos eram os seriados norte-americanos de heróis. A procedência das películas era, sobretudo, internacional, visto que os filmes nacionais não eram muito prestigiados pelos nossos depoentes. A depoente Sigrid diz que "gostava muito de filme romântico, e dos musicais da Broadway. [...] Filme nacional era muita chanchada, não aproveitava muito. Se bem que tinha uns bem bons". Essas produções não ocupavam grande espaço nas programações, pois o público esperava avidamente os filmes hollywoodianos. A proeminência na programação era das películas norte-americanas, cujos artistas mais importantes foram constantemente citados: Marilyn Monroe, Doris Day, Rita Hayworth, Marlon Brando, Charlton Heston, etc. Porém, os filmes europeus nesse período tinham uma presença muito forte que posteriormente se enfraqueceu. Por muito tempo, os westerns italianos, chamados spagguetti, fizeram grande sucesso nos cinemas locais. Além disso, as matérias do jornal apresentavam, a cada pouco, filmes franceses, italianos, suecos, alemães, tchecos, poloneses, entre outros..

${ }^{38}$ Entrevista com Sigrid Esther Shilling. Março de 2008.

39 Notas recolhidas. Jornal NH. Novo Hamburgo, 04/06/1960, p. 4.

${ }^{40}$ Cinemas: desordeiros prejudicam sessões. Jornal NH. Novo Hamburgo, 09/08/1963, p. 19.

4) Entrevista com Anny Bertrudes Engelmann. Março de 2008.

${ }^{42}$ Entrevista com Paulo Reichert. Maio de 2008.

${ }^{43}$ RAMOS, Eloísa Helena Capovilla da Luz. O teatro da sociabilidade: um estudo dos clubes sociais como espaço de representação das elites urbanas alemãs e teuto-brasileiras: São Leopoldo 1850/1930. 2000. Tese (Doutorado em História) - Instituto de Filosofia e Ciências Humanas, Universidade Federal do Rio Grande do Sul, Porto Alegre, 2000. P. 49.

${ }^{44}$ Ibidem, p. 63.

${ }^{45}$ Ibidem, p. 31.

${ }^{46}$ Propaganda televisor Admiral. Jornal NH. Novo Hamburgo, 29/I I/I965, p. 5.

${ }^{47}$ Cinema versus TV. Jornal NH. Novo Hamburgo, 04/06/1965, p. 6.

48 Ibidem.

49 Ibidem.

50 TURNER, Graeme. Cinema como prática social. São Paulo: Summus, 1997.

${ }^{51}$ O Cinema está em decadência? Jornal NH. Novo Hamburgo, 19/09/1969, p. 13.

52 Ibidem.

${ }^{53}$ Ibidem.

${ }^{4}$ MALVERDES, André. No escurinho do cinema: a história das salas de exibição na Grande Vitória. Vitória: editora?, 2008.

${ }^{55}$ GATTI, André. Exibição. In: RAMOS, Fernão Pessoa; MIRANDA, Luiz Felipe A. de (Orgs). Enciclopédia do Cinema Brasileiro. São Paulo: ed. SENAC, 2000.

${ }^{55}$ Lauro Diogo de Jesus. Jornal NH. Novo Hamburgo, I2/I I/I97।, p. 2.

${ }^{56}$ Entrevista com Hedviges Terezinha Erkens Fischer. Março de 2008. 
${ }^{58}$ Entrevista com Cláudio Luiz Bender. Maio de 2008.

59 Entrevista com Sigrid Esther Shilling. Março de 2008.

60 Uma avenida que tem rádio, cinema e hospital. Jornal NH. Novo Hamburgo, 31/01/1969, p. 12. SPLINDER, Walkíria. Nôvo Cine Avenida. Jornal NH, Novo Hamburgo, 14 fev. 1969. Gente \& Sociedade, p.4. Walkíria Spindler. Gente \& Sociedade. Jornal NH. Novo Hamburgo, 28 fev. 1969, p. 7. Jota Feio. Gente Importante. Jornal NH. Novo Hamburgo, 07 mar. 1969, p. 16. Jota Feio. Gente Importante. Jornal NH. Novo Hamburgo, 19 mar. 1969, p. 16. Walkíria Spindler. Gente \& Sociedade. Nôvo Cine Avenida. Jornal NH. Novo Hamburgo, 23 abr. 1969, p. 5. Walkíria Spindler. Gente \& Sociedade. Cinema Avenida. Jornal NH. Novo Hamburgo, II jun. 1969, p. 7. José Luiz Schmitt. Só para Jovens. Caderno 2. Jornal NH. Novo Hamburgo, 16 jan. 1970, p. 2.

${ }^{61}$ Jota Feio. Gente Importante. Jornal NH. Novo Hamburgo, 04 jul. 1969, p. 12. Maria Helena Corrêia e Silva. Gente \& Sociedade. Jornal NH. Novo Hamburgo, 27/06/1969, p. 8.

${ }^{62}$ Jota Feio. Gente Importante. Jornal NH. Novo Hamburgo, 28 jan. 1970, p. 12.

${ }_{63}$ Cine Aída está fechando as portas. Jornal NH. Novo Hamburgo, 29 set. 1976, Capa; Cine Aida Fechou: O público perde outra casa de espetáculos. Jornal NH. Novo Hamburgo, 04 out. 1976, p. 2. ${ }^{64} \mathrm{O}$ que está acontecendo com o cinema? Jornal NH. Novo Hamburgo, 18 set. 1974, p. 6.

${ }^{65}$ Qual é a sua opinião? A qualidade dos filmes dos cinemas locais. Jornal NH. Novo Hamburgo, 08 ago. 1979, p. 23.

${ }^{66}$ Cidade perde um pedaço de sua história. Lumière teve ontem sua última sessão. Jornal NH. Novo Hamburgo, 13 set. 1982, p. 6 e 12.

${ }^{67}$ REICHERT, Evânia. Artistas querem manter o Cine Lumière funcionando. Jornal NH, Novo Hamburgo, 06 dez. 1982. Capa e p. 6.

${ }^{68}$ FElJÓ, Alceu. O Adeus dos Namorados. Jornal NH. Novo Hamburgo, 13 set. 1982. P. 12.

${ }^{69}$ Shopping completa dois anos. Jornal NH. Novo Hamburgo, 21 out. 1993, Capa.

70 SELBACH, op. cit., p. 240-24l.

${ }_{71}$ Novo Shopping abre hoje como o maior do interior. Jornal NH. Novo Hamburgo, 23 out. 1991, p. 13.

72 Novo Shopping abre com grande público. Jornal NH. Novo Hamburgo, 25 out. 1991, Capa.

73 SELBACH, op. cit., p. 237.

${ }^{74}$ Geração Shopping Center. Caderno de Domingo. Jornal NH. Novo Hamburgo, 24 nov. 1990, p. 14.

${ }^{75}$ Novo Shopping completa dois anos de sucesso. Jornal NH. Novo Hamburgo, 21 out. 1993, Capa.

${ }^{76}$ Cine Avenida fechou ontem. Jornal NH. Novo Hamburgo, 01 dez. 1989, Capa.

77 FLORES, Adriano. O que passa com os cinemas. Jornal NH, Novo Hamburgo, 23 e 24 jul. 1994.

Caderno de Domingo, Capa, p. 4 e 5.

78 Ibidem.

79 Entrevista com José Carlos Blankenheim. Abril de 2008.

${ }^{80}$ Adeus aos "cinemões". Jornal NH. Novo Hamburgo, 23 jun. 1995, p. 35.

${ }^{81}$ Coluna Sabe-Tudo. Jornal NH. Novo Hamburgo, 10 abr. 1997, p. 2.

82 Ibidem.

${ }^{83}$ WEISSHEIMER, Julio. Weissheimer. Lojista. Carta do Leitor. Jornal NH. Novo Hamburgo, 08 jul. 1996, p. 3.

${ }^{84}$ Depoente Hedviges Fischer. Grifo nosso.

${ }^{85}$ HALBWACHS, op. cit., p. 81.

86 POLLAK, Michael. Memória e Identidade Social. Revista Estudos Históricos, Rio de Janeiro, vol. 5, n. 10, p. 207, 1992.

${ }^{87}$ Idibem, p. 205.

${ }^{88}$ Entrevista com José Carlos Blankenheim. Abril de 2008.

89 Sobre a questão da crise do projeto moderno nas grandes cidades, destaca-se o trabalho de Luiz Maroneze, ao analisar os efeitos desta temática na cidade de Porto Alegre. MARONEZE, Luiz Antônio Gloger. Porto Alegre em dois cenários: nostalgia da modernidade no olhar dos cronistas. 2007. Tese (Doutorado em História) - Pontifícia Universidade Católica do Rio Grande do Sul, Porto Alegre, 2007. 258 p. 
68 REVISTA ESBOÇOS Volume 16, № 21, pp. 41-68 - UFSC

90 ZANELLA, Cristiano. The End: Cinemas de calçada em Porto Alegre (1990-2005). Porto Alegre: Idéias a Granel, 2006, p. 97. 